\title{
Characteristics of Ascitic Fluid in the Alcoholic Cirrhotic
}

\author{
JOANNE A.P. WILSON, MD, EDEN A. SUGUITAN, MD, WILLIAM A. CASSIDY, MD, \\ RICHARD H. PARKER, MD, and CHAO H. CHAN, MD
}

\begin{abstract}
A prospective study was conducted to define the characteristics of ascitic fluid in alcoholic cirrhotics with and without spontaneous bacterial peritonitis (SBP); to correlate these with findings in the peripheral blood; and to determine whether the use of counterimmunoelectrophoresis (CIE) for bacterial antigens will aid in the early diagnosis of SBP. Fifty-one alcoholic cirrhotics had simultaneous determination of their blood or serum and ascitic fluid for the following: WBC and differential count, $R B C, L D H$, amylase, glucose, total protein, and protein electrophoresis, CIE for pneumococcal and Klebsiella antigens, culture for aerobic and anaerobic bacteria and mycobacteria, and cytology. Of the 51 patients, 2 had SBP (4\%). In the other 49 patients (54 sera and ascitic fluids), CIE was positive for pneumococcal antigen in 4/54 sera and in 3/54 ascitic fluids. The mean WBC count in the ascitic fluid was 349 . In $4 \%$ the count was above 1000 , in $18 \%$ between $501-$ 1000 , and in 32\% between 301-500; polymorphs were $>30 \%$ in 19/54 (32\%). Specific gravity was $>1.020$ in $10 / 54(22 \%)$, and ascitic fluid total protein of $3.0 \mathrm{~g} / 100 \mathrm{ml}$ or above was noted in 24\% (12/54). Mean ascitic fluid/serum ratios of total protein, albumin, and globulin were $0.31,0.33$, and 0.30 respectively, and mean ascitic fluid/serum ratios of $L D H$, amylase, and glucose were 0.54, 0.79, and 1.04. All cultures (except those with SBP) and cytology were negative. Our study confirmed the observation of others, that a significant number of noninfected cirrhotics have increased ascitic fluid WBC, \% polymorphs, specific gravity, and total protein concentration. CIE was not helpful in the early diagnosis of $S B P$.
\end{abstract}

There have been a number of reports describing the characteristics of the ascitic fluid of cirrhotic patients (1-8), but until recently, none have represented prospective studies. The only prospective analysis of ascitic fluid in cirrhotic patients was reported in 1976 by Kline et al (9). A similar prospective study, initiated prior to the latter report, was conducted at this hospital. The purpose of the study was to define prospectively the characteristics of ascitic fluid in the alcoholic cirrhotic; to correlate the ascitic fluid findings with those of the peripheral blood; and to determine whether the use of counterimmunoelectrophoresis (CIE) for detection of bac-

From the Medical Service, Veterans Administration Hospital, Washington, D.C.

Address for reprint requests: Dr. Joanne A.P. Wilson, Department of Internal Medicine, University of Michigan, Ann Arbor, Michigan 48109. terial antigens would aid in the early diagnosis of spontaneous bacterial peritonitis (SBP). Although the detection of bacterial antigens in other body fluids such as pleural and cerebrospinal fluid by counterimmunoelectrophoresis has been advocated for the rapid diagnosis of bacterial infection, its use in the diagnosis of spontaneous bacterial peritonitis has not been reported previously $(10,11)$.

\section{MATERIALS AND METHODS}

Patients considered for inclusion in the study were admitted to the Veterans Administration Hospital, Washington, D.C., between October 1, 1974, and December 31, 1975. All had chronic alcoholism and cirrhosis. The diagnosis of cirrhosis was documented by liver biopsy in 22 of the 51 patients. In the remaining 29 patients, the diagnosis of cirrhosis was made clinically. All patients had unequivocal evidence of ascites on physical examina- 
WILSON ET AL

tion, defined by the presence of a positive fluid wave and/ or shifting dullness of $4 \mathrm{~cm}$ or more. Paracentesis was performed by a member of the Gastroenterology Service within $72 \mathrm{hr}$ of the patient's admission to the hospital. Patients were excluded if they had had recent previous paracentesis by housestaff. The paracentesis was performed with an 18-gauge Longdwell catheter needle, along the linea alba, approximately midway between the umbilicus and the symphysis pubis, or in the left lower abdominal quadrant. Using aseptic techniques, $150 \mathrm{ml}$ of ascitic fluid was removed and examined for specific gravity, red blood cell count, white blood cell count by Hemocytometer, differential cell count, glucose, amylase, lactic dehydrogenase (LDH), total protein and protein electrophoresis, and cytology for malignant cells. Aerobic and anaerobic cultures were performed by the Infectious Disease Research Laboratory. Specimens were immediately plated on Columbia sheep blood agar, MacConkey agar, and Feldes peptic digest of blood agar, and inoculated into trypticase soy broth and L-form broth for isolation of aerobic bacteria. Anaerobic cultures were done using prereduced media according to the VPI method (12). The sediment from $50 \mathrm{ml}$ of ascitic fluid was cultured for mycobacteria. Peripheral venous blood was drawn from patients just prior to paracentesis for simultaneous white blood cell count and differential count, amylase, glucose, LDH, total protein, protein electrophoresis, and cultures. Counterimmunoelectrophoresis (CIE) for pneumococcal and Klebsiella antigens was performed on serum and ascitic fluid by the Infectious Disease Research Laboratory using the method described by Edwards (13).

\section{RESULTS}

The 51 patients studied ranged in age from 34 to 63 years. All but one were males. Of the 51 patients, 47 had one paracentesis; three had two paracenteses, performed 3 weeks, 4 weeks, and 5 months apart; one patient had three paracenteses separated by 2 weeks and 6 weeks.

Symptoms suggestive of the presence of peritonitis are summarized in Table 1. Features of alcoholic cirrhosis, such as jaundice, hepatosplenomegaly, or dilated abdominal venous collaterals are excluded from the table. The diagnosis of pancreatitis was made in only 5 patients; none of the patients had hepatocellular carcinoma.

Of the 51 patients studied, the diagnosis of bacterial peritonitis was made in only 2 (Table 2). Both had fever, peripheral blood leukocytosis of 11,300 and 15,500 , ascitic fluid leukocytosis of 5833 and 3800 , and ascitic fluid polymorph counts of $91 \%$. Neither of the two patients had abdominal tenderness. In patient 1 , CIE tests on the ascitic fluid were positive for Klebsiella antigen although the culture showed no growth. However, the simultaneous blood culture was positive for Streptococcus pneu-
Table 1. Symptoms of Peritonitis at Time of Diagnostic Paracentesis

\begin{tabular}{lccc}
\hline \multicolumn{1}{c}{ Symptoms } & $\begin{array}{c}\text { Total no. } \\
\text { patients }\end{array}$ & $\begin{array}{c}\text { No. } \\
\text { positive }\end{array}$ & $\begin{array}{c}\% \\
\text { positive }\end{array}$ \\
\hline Abdominal pain & 51 & 3 & 6 \\
Abdominal tenderness & & & \\
$\quad$ With rebound & 51 & 2 & 4 \\
$\quad$ Without rebound & 51 & 9 & 17 \\
Fever & 51 & 16 & 32 \\
\hline
\end{tabular}

moniae but the serum CIE test was negative. He died as a result of massive esophageal variceal bleed despite improvement of his SBP. The other infected patient's (patient 2) ascitic fluid was culture positive for enterococci. He responded to antibiotic treatment and was discharged from the hospital 7 weeks later. The remaining 49 patients had negative aerobic and anaerobic cultures of their ascitic fluids and peripheral blood. All 56 ascitic fluids studied had negative cultures for mycobacteria. The results of CIE tests in the 4 patients (patients 3-6) with positive pneumococcal antigen but without evidence of SBP are summarized in Table 2. One patient had pneumococcal meningitis, but no clinical or autopsy evidence of peritonitis. In the remaining three patients with positive pneumococcal antigen, all bacterial cultures of their ascitic fluid and blood were negative. The follow-up clinical course did not indicate the presence of any active infection. Cytology of ascitic fluid was negative for malignant cells in all 51 patients.

The characteristics of the ascitic fluid in the 49 noninfected alcoholic cirrhotics are summarized in Table 3. The white blood cell count was above 1000 in 2 patients $(4 \%)$, between 501 and 1000 in $9(18 \%)$, between 301 and 500 in $17(32 \%)$, and 300 or less in $25(46 \%)$. The percent polymorphonuclear leukocyte count was greater than $30 \%$ in 19 (35\%). The specific gravity was above 1.020 in $10(22 \%)$. The ascitic fluid to serum (AF/S) ratios of total protein, albumin and globulin were $0.31,0.33$, and 0.30 respectively; however, the AF/S ratios of $\mathrm{LDH}$, amylase, and glucose were $0.54,0.79$, and 1.04 . There was a significant correlation between the serum and ascitic fluid total protein $(r=0.30, P<0.05)$, albu$\min (r=0.48, P<0.001)$, amylase $(r=0.31, P<$ $0.05)$, glucose $(r=0.83, P<0.001)$, but not for LDH $(r=0.10, P>0.05)$ and globulin $(r=0.23, P$ $>0.05)$. The mean \pm SD of total protein and WBC counts in the ascitic fluids of patients on diuretics was $2.15 \pm 1.13$ and $249 \pm 213$, as compared to non- 
ASCITIC FLUID IN THE ALCOHOLIC CIRRHOTIC

Table 2. Summary of Bacterial Cultures and CiE Tests in 51 Patients With and Without SBP

\begin{tabular}{|c|c|c|c|c|c|c|c|}
\hline \multirow{2}{*}{$\begin{array}{c}P a- \\
\text { tient } \\
\text { no. }\end{array}$} & \multicolumn{3}{|c|}{ Blood } & \multicolumn{3}{|c|}{ Ascitic Fluid } & \multirow[b]{2}{*}{ Comments } \\
\hline & Culture & $C I E$ & $\begin{array}{c}\text { WBC } \\
\% \text { polys }\end{array}$ & Culture & $C I E$ & $\begin{array}{c}W B C \\
\% \text { polys }\end{array}$ & \\
\hline 1 & $\begin{array}{l}+ \text { Strep. } \\
\text { pneumoniae }\end{array}$ & - & $11,300(91 \%)$ & - & + Klebsiella & $5,833(91 \%)$ & $\begin{array}{l}\text { Spontaneous bacterial } \\
\text { peritonitis }\end{array}$ \\
\hline 2 & - & - & $15,500(79 \%)$ & + Enterococci & - & $3,833(91 \%)$ & $\begin{array}{l}\text { Spontaneous bacterial } \\
\text { peritonitis }\end{array}$ \\
\hline 3 & - & + Pneum. type 9 & $15,700(87 \%)$ & - & +Pneum. type 9 & $400(44 \%)$ & Pneumococcal meningitis \\
\hline 4 & - & +Pneum. type 2 & $9,900(74 \%)$ & - & +Pneum. type 2 & $217(32 \%$ & Acute alcoholic hepatitis \\
\hline 5 & - & $\begin{array}{l}\text { +Pneum. not } \\
\text { typable }\end{array}$ & $14,800(80 \%)$ & - & $\begin{array}{l}\text { Pneum. not } \\
\text { typable }\end{array}$ & $448(7 \%)$ & Acute alcoholic hepatitis \\
\hline 6 & - & +Pneum. type 3 & $19,600(81 \%)$ & - & - & $140(92 \%)$ & Acute alcoholic hepatitis \\
\hline $7-51$ & - & - & $\begin{array}{c}3,200- \\
41,200 \\
(51-90 \%)\end{array}$ & - & - & $\begin{array}{l}12-1,094 \\
(0-100 \%)\end{array}$ & No clinical infection \\
\hline
\end{tabular}

diuretic-treated group of $2.09 \pm 1.17$ and $388 \pm 273$. This difference was not statistically significant $(P>$ 0.05 ). Protein electrophoresis of the ascitic fluids revealed distribution of various protein fractions similar to that in the serum, but at about $30 \%$ of serum concentration.

\section{DISCUSSION}

The incidence of spontaneous bacterial peritonitis was only $4 \%(2 / 51)$ in our prospective series, lower than the $8 \%$ reported by Kline et al (9) and by Conn and Fessel (7). In view of the possibility that the design of our study may have selectively excluded the sicker infected patients, we reviewed records of all ascitic fluids cultured by the Clinical Microbiology Laboratory from October 1, 1975, to December 31, 1975. A total of 53 ascitic fluids were cultured from 44 patients. Two patients had positive ascitic fluid culture for bacteria (Enterobacter and $E$. coli). The incidence of SBP calculated from this retrospective review was $4.5 \%$. We do not believe that the lower incidence of SBP at our hospital can be explained on the basis of a lack of suspicion on the part of the physicians, since almost all cirrhotic patients who had a change in their clinical status had paracentesis performed to rule out SBP. We have not had any positive ascitic fluid cultures for anaerobic bacteria at our hospital. The rarity of spontaneous bacterial peritonitis due to anaerobic bacteria has been noted by others (14).

The mean WBC count of 349 (ascitic fluid) in our study is quite similar to that of Kline et al (9) and Conn and Fessel (7); however, $54 \%$ of our noninfected patients had ascitic fluid WBC count above 300. This figure is similar to that reported by Kline (9) but much higher than the $17 \%$ reported by Conn and Fessel (7). The higher WBC count could not be attributed to the presence of pancreatitis in our patients when our data were correlated with the clinical picture. Both of our infected patients with SBP had differential count in the ascitic fluid of more than $90 \%$ neutrophils. The WBC count in the ascitic fluid did not correlate with the peripheral blood WBC count $(r=0.07)$. Although the ascitic fluid total protein and WBC count in the diuretic-treated group did not differ significantly. $(P>0.05)$ from the group on no diuretics, the influence of diuretic treat-

Table 3. Characteristics of Ascitic Fluid in 49 Noninfected Patients

\begin{tabular}{|c|c|c|c|c|c|c|}
\hline \multirow[b]{2}{*}{ Tests } & \multicolumn{2}{|c|}{ Ascitic fluid } & \multicolumn{2}{|c|}{ Blood } & \multicolumn{2}{|c|}{ Ascitic fluid/serum ratio } \\
\hline & Mean \pm SD & Range & Mean $\pm \mathrm{SD}$ & Range & Mean $\pm \mathrm{SD}$ & Range \\
\hline WBC count & $349 \pm 263$ & $12-1095$ & $10,400 \pm 6,800$ & $3,200-25,300$ & & \\
\hline$\%$ Polymorphonuclears & $31 \pm 32$ & $0-100$ & $73 \pm 12$ & $51-94$ & & \\
\hline Specific gravity & $1.016 \pm 0.006$ & $1.005-1.031$ & & & & \\
\hline Total protein & $2.11 \pm 1.15$ & $0.5-5.5$ & $6.92 \pm 1.0$ & $3.8-9.7$ & $0.31 \pm 0.16$ & $0.08-0.70$ \\
\hline Albumin & $0.83 \pm 0.68$ & $0.1-3.5$ & $2.47 \pm 0.51$ & $1.4-3.5$ & $0.33 \pm 0.21$ & $0.04-1.03$ \\
\hline Globulin & $1.28 \pm 0.63$ & $0.2-2.5$ & $4.45 \pm 1.07$ & $1.6-7.4$ & $0.30 \pm 0.16$ & $0.04-0.77$ \\
\hline LDH & $100 \pm 92$ & $12-650$ & $243 \pm 108$ & $55-510$ & $0.54 \pm 0.71$ & $0.09-2.60$ \\
\hline Glucose & $136 \pm 41$ & $55-338$ & $134 \pm 50$ & $60-425$ & $1.04 \pm 0.25$ & $0.50-1.84$ \\
\hline Amylase & $81 \pm 77$ & $0-535$ & $189 \pm 417$ & $50-3000$ & $0.79 \pm 0.57$ & $0.05-3.18$ \\
\hline
\end{tabular}


ment on the ascitic fluid protein concentration and WBC count can only be answered by prospective serial paracentesis in individual patients performed prior to and during diuretic therapy. The $24 \%$ frequency of ascitic fluid protein concentration greater than $3.0 / 100 \mathrm{ml}$ in our study is comparable to the $19 \%$ reported by Iber (8) in a retrospective series. Ascitic fluid specific gravity above 1.020 was also noted in $22 \%$ of our noninfected patients. The mean AF/S ratios of total protein, albumin, and globulin were almost identical $(0.31,0.33,0.30)$. Rovelstad et al (2) noted similar low AF/S ratios of albumin and globulin in cirrhotics. Of more interest, however, is the significant correlation between serum and ascitic fluid total protein and albumin which may explain some of the variability observed in ascitic protein levels in these patients. Of note, the $\mathrm{AF} / \mathrm{S}$ ratios of $\mathrm{LDH}$, amylase, and glucose $(0.54$, $0.79,1.04$ ) were much higher.

CIE testing for the presence of pneumococcal antigen yielded positive results in the sera of 4 patients (Table 2). In 3 of the 4 patients, their ascitic fluids were also positive. Patient 3 , whose serum and ascitic fluid were both positive by CIE, had documented pneumococcal meningitis. He had no evidence of peritonitis clinically or at autopsy. Since the pneumococcal antigen is a soluble antigen, a positive ascitic fluid CIE for pneumococcal antigen does not necessarily indicate peritoneal infection, and when accompanied by a positive CIE test in the serum, may indicate infection at another site. In the remaining 3 patients with positive CIE in the serum, the positive test could be attributed to a subclinical pneumococcal infection, or alternatively, the pneumococcal antigen may have persisted after a previous infection. The reliability of the positive CIE test for pneumococcal antigen was supported by the finding that in two of these three patients, there was a very distinct precipitin band with typespecific antisera by the CIE test. A major limitation of CIE testing for rapid diagnosis of SBP is the present lack of availability of polyvalent antisera to $E$. coli, one of the common bacteria involved in SBP. However, the increased prevalence of anti-E. coli antibody in the sera of cirrhotic patients (15) may interfere with CIE testing by antigen-antibody complexing, with false negative test results. Therefore, CIE testing, as presently available, does not appear to be an aid in the early diagnosis of SBP.

The mortality rate of SBP in our study could not be adequately assessed due to the small number of infected patients. The high mortality rate of $31 \%$ $(15 / 49)$ in our noninfected patients suggests that the severity of the patient's underlying liver disease and its complications (acute alcoholic hepatitis, gastrointestinal bleeding, hepatorenal syndrome) may have been responsible in part for the enormously high mortality rate reported by Conn and Fessel (7) in his patients with SBP. Early recognition and treatment of SBP may reduce but not eliminate the high mortality rate of alcoholic cirrhotic patients with spontaneous bacterial peritonitis.

\section{REFERENCES}

1. Paddock FK: The diagnostic significance of serous fluids in disease. N Eng J Med 223:1010-1015, 1940

2. Rovelstad RA, Bartholomew LG, Cain JC, et al: Ascites. I. The value of examination of ascitic fluid and blood for lipids and for protein electrophoresis. Gastroenterology 34:436450,1958

3. Fleisher GA, Bartholomew LG, Cain JC, et al: Ascites. II. The value of determinations of enzymes in the study of ascitic fluid. Gastroenterology 37:325-331, 1959

4. McGuckin WF, Soule EH, Cain JC, et al: Ascites. III. The value of glycoprotein determination and cytology in the study of ascitic fluid. Gastroenterology 37:332-338, 1959

5. Rovelstad RA, Bartholomew LG, Cain JC: Ascites. IV. Clinical appraisal of the laboratory studies of ascitic fluid and blood as an aid to diagnosis. Gastroenterology 37:339345,1959

6. Travel ME: Ascites: Etiologic considerations with emphasis in the value of several laboratory findings in diagnosis. Am J Med Sci 237:727-742, 1959

7. Conn HO, Fessel JM: Spontaneous bacterial peritonitis: variations on a theme. Medicine 50:161-197, 1971

8. Sampliner SE, Iber FL: High protein ascites in patients with uncomplicated hepatic cirrhosis. Am J Med Sci 267:275-279, 1974

9. Kline MM, McCallum RW, Guth PH: The clinical value of ascitic fluid culture and leukocyte count studies in alcoholic cirrhotics. Gastroenterology 70:408-412, 1976

10. Lampe RM, Chottipitayasunondh T, Sunakorn P: Detection of bacterial antigen in pleural fluid by counterimmunoelectrophoresis. J Pediatr 88:557-560, 1976

11. Fossieck B, Craig R, Paterson PY: Counterimmunoelectrophoresis for rapid diagnosis of meningitis due to Diplococcus pneumoniae. J Infect Dis 127:106-109, 1973

12. Holdman LV, Moore WEC (eds): Anaerobic Laboratory Manual, 3rd ed. Blacksburg, Virginia, Southern Printing Co., 1975

13. Edwards EA: Immunologic investigation of meningococcal disease. J Immunol 106:314-317, 1971

14. Targan SR, Chow AW, Guse LB: Role of anaerobic bacteria in spontaneous peritonitis of cirrhosis. Am J Med 62:397, 1977

15. Triger DR, Alp MH, Wright R: Bacterial and dietary antibodies in liver disease. Lancet 1:60-63, 1972 